\title{
Investigation of low back pain in a non-hospital population of the coastline of the State of São Paulo*
}

\author{
Investigação da lombalgia em população não hospitalar no litoral paulista \\ Janaína Macedo Malateaux ${ }^{1}$, Flávia Rother Ricci ${ }^{1}$, Yára Dadalti Fragoso, MD, MSc, PhD² \\ ${ }^{*}$ Received from Universidade Metropolitana de Santos, SP, Brazil.
}

\section{SUMMARY}

BACKGROUND AND OBJECTIVES: Low back pain is a prevalent complaint of multifactorial origins. To date, there have been no studies on the prevalence and characteristics of low back pain in the city of Santos, in the coastal region of the State of São Paulo, Brazil. The objective of the present study was to assess the profile of middle-aged individuals with low back pain from the general population aged 40-59 years, regarding gender, body mass index, regular physical activity and load handling.

METHOD: The study design was prospective, exploratory and transversal, comprising 200 adults aged between 40 and 59 years, randomly selected as the study population. These individuals were sequentially approached by the researchers and asked whether they would agree to answer a medical questionnaire. No indication of the intention of researching low back pain was given before the individuals had agreed to participate.

RESULTS: Out of 200 individuals (78 males and $122 \mathrm{fe-}$ males), 159 of them (60 males and 99 females) answered that they had experienced at least one significant and limiting episode of low back pain in their lives. A subgroup of 109 individuals (37 males and 72 females) had sought medical care for this painful episode. There were no statistically significant differences regarding gender, body

1. Undergraduate Medical Students of Universidade Metropolitana de Santos. Santos, SP, Brazil.

2. Head of the Department of Neurology of Universidade Metropolitana de Santos. Santos, SP, Brazil.

Corresponding author:

Yára Dadalti Fragoso

Department of Neurology, Medical School, UNIMES

Rua da Constituição 374

11015-470, Santos SP, Brazil.

Phone/fax: +55 1332263400

E-mail: yara@bsnet.com.br mass index or number of hours sitting down at work and the presence of low back pain. There was a small positive correlation between low back pain and load handling at work, as well as a slight negative correlation between low back pain and regular physical activity.

CONCLUSION: Low back pain was a highly prevalent condition in otherwise healthy individuals in our region.

Keywords: Low back pain, Pain, Physical activity.

\section{RESUMO}

JUSTIFICATIVA E OBJETIVOS: A lombalgia é uma queixa prevalente de origem multifatorial. Até hoje não existem estudos sobre a prevalência e as características da lombalgia na cidade de Santos, no litoral do estado de São Paulo, Brasil. O objetivo deste estudo foi avaliar o perfil de indivíduos de meia idade com lombalgia na população entre 40 e 59 anos de idade, com relação ao sexo, índice de massa corporal, atividade física regular e manuseio de carga.

MÉTODO: Estudo prospectivo, exploratório e transversal, envolvendo 200 adultos com idades entre 40 e 59 anos, escolhidos aleatoriamente. Os indivíduos foram abordados sequencialmente pelos pesquisadores que perguntaram se concordariam em responder a um questionário médico. Nenhuma indicação da intenção de pesquisar a lombalgia foi dada antes que as pessoas concordassem em participar.

RESULTADOS: Dos 200 indivíduos (78 homens e 122 mulheres), 159 (60 homens e 99 mulheres) responderam que haviam passado por pelo menos um episódio importante e limitante de lombalgia em suas vidas. Um subgrupo de 109 pessoas (37 homens e 72 mulheres) havia buscado tratamento médico para esse episódio doloroso. Não houve diferença estatisticamente significante em gênero, índice de massa corporal ou número de horas sentados no trabalho e a presença de lombalgia. Houve uma pequena 
correlação positiva entre lombalgia e manuseio de carga no trabalho, bem como uma pequena correlação negativa entre lombalgia e atividade física regular.

CONCLUSÃ̃: A lombalgia foi uma condição altamente prevalente em pessoas saudáveis de nossa região.

Descritores: Atividade física, Dor, Lombalgia.

\section{INTRODUCTION}

Chronic low back pain is an important health care problem, affecting 5\%-30\% of adults in different large population studies ${ }^{1,2}$, including Brazil ${ }^{3}$. The prevalence of this condition seems to be constantly rising ${ }^{4}$ in all ethnic groups $^{5}$, generating higher medical and societal costs ${ }^{6}$. Obesity seems to be an independent risk factor for low back pain ${ }^{7}$, while a sedentary lifestyle ${ }^{8}$ and occupational postures ${ }^{9}$ do not seem to be independently related to this chronic condition. Distorted beliefs regarding the disease $^{10}$ and claims for financial compensation ${ }^{11}$ are highly prevalent among individuals with chronic low back pain. Therefore, there is an undisputable need for an educational program as part of the patients' treatment ${ }^{12}$. In addition to the high prevalence of low back pain and the inherent difficulties in its assessment, proper definitions for chronicity and recurrence have not been clearly established ${ }^{13}$.

To date, there are no published studies on low back pain in the population of otherwise healthy individuals in the city of Santos, State of São Paulo, Brazil. The aim of the present pilot work was to assess the prevalence of low back pain leading to medical consultations in a group of adults in their fourth and fifth decades of life, living in Santos, SP. In addition to the positive or negative history of low back pain, body mass index (BMI), occupational factors, and regular exercising were investigated among these individuals.

\section{METHOD}

This study was approved by the Ethics Committee of Universidade Metropolitana de Santos, under the number 006/2010. All participants were residents of the the city of Santos, state of São Paulo, and volunteered to answer the questions. They gave their consent to the use of the data obtained, provided that confidentiality was guaranteed.

The study design was prospective, exploratory and cross-sectional. Two hundred adults aged between 40 and 59 years were randomly selected as the study population. These individuals were standing in queu- es, shopping or walking around the streets, etc., when they were sequentially approached by the researchers and asked whether they would agree to answer a medical questionnaire. There was no immediate indication that the nature of the study was related to low back pain, in order to avoid bias (individuals with pain might be more prone to answering a questionnaire on the subject). Only individuals in general good health and fully capable of walking were included in the study. This pilot study did not aim towards enquiring about or analyzing the degree of pain and its impact.

All data were collected individually by two medical students, who had been trained to carry out this study. Demographic data (gender and age) were obtained. Personal histories of low back pain, including any requirement to attend a medical consultation due to this condition, were investigated. In addition, respondents were asked to state their height and weight, so that BMI could be calculated, and their professional history was obtained, including the number of hours spent sitting in a chair, or whether the work required load handling. Finally, each individual's exercise activity was recorded, considering only regular physical activity (more than once a week).

Mean values and standard deviations (SD) were used for continuous variables. Student's t-test was used to assess the significance of differences. The degree of linear agreement between parameters was calculated using the Pearson correlation coefficient. Values were considered to be significant when $p \leq 0.05$. Odds ratios were expressed with their $95 \%$ confidence interval (CI).

\section{RESULTS}

From the initial group of 200 individuals ( 78 males and 122 females), 159 of them (60 males and 99 females) answered that they had experienced at least one significant and limiting episode of low back pain in their lives. A subgroup of 109 individuals (37 males and 72 females) who had sought medical care for this painful episode (whether acute or chronic) was then selected for analysis.

Statistical analysis on the subgroups showed that there were no higher odds for a given gender to have low back pain or to seek medical help in the event of this condition. Likewise, there were no higher odds for individuals with $\mathrm{BMI} \geq 25 \mathrm{~kg} / \mathrm{m} 2$ to present low back pain $(\mathrm{OR}=0.868$; $95 \% \mathrm{CI}: 0.468$ to 1.609$)$ or, if presenting it, to seek medical help $(\mathrm{OR}=1.172 ; 95 \% \mathrm{CI}$ : 0.6184 to 2.222 ). There were no statistically significant 
differences in the number of hours per day that individuals spent sitting down at work $(5.12 \pm 3.56$ for individuals without pain, $5.7 \pm 3.44$ for those with pain who had sought medical care, and $5.38 \pm 3.07$ for those with pain who had not sought medical care).

The chance that an individual with low back pain would handle loads at work was marginally higher than for individuals who did not handle loads at work (OR $=1.805 ; 95 \%$ CI: 0.761 to 4.279$)$. There were no differences in the characteristic of seeking medical care among individuals handling loads at work and having low back pain, i.e. medical care was equally sought (or not) by those who presented low back pain and handled loads regularly at work $(\mathrm{OR}=0.9461 ; 95 \% \mathrm{CI}: 0.477$ to 1.876$)$. Another marginally significant result was observed in relation to regular physical activity, since the individuals without any low back pain had a slightly higher chance of regularly exercising $(\mathrm{OR}=1.7063$; 95\% CI: 0.929 to 3.133 ).

\section{DISCUSSION}

A recent Brazilian review of the literature ${ }^{14}$ highlighted the socioeconomic impact and the multifactorial characteristics of low back pain. Their review discussed in detail what the requirements were for a multidisciplinary team to attend these patients, the need to understand the financial gains from the disease, the family's influence on perpetuating the pain, as well as the beliefs and catastrophic attitudes of patients. Along with other factors involved in the etiology of this condition, low back pain is indeed a very difficult condition to manage and treat. In fact, it is rare to observe low back pain specifically triggered by only one factor or condition ${ }^{15}$. The effect of low back pain in the quality of life has also been recently reported in a Brazilian population ${ }^{16}$.

The aim of the present work was to start an investigation on the factors associated with low back pain in our region, comprising a population aged $40-59$ years. It was expected that the age selection limited low back pain to a smaller group of etiological categories. The subject of our study was highly relevant, since $54.5 \%$ of the study population had, at least once in their lives, sought medical care for low back pain. A recent Danish study concluded that disabling low back pain is exceedingly rare before the age of $50^{17}$, while a North-American group reported that general disc diseases were the most important cause of low back pain in middle-aged adults ${ }^{18}$. Another recent paper, this time from Spain, discusses the high prevalence of low back pain in several age groups, highlighting the low quality of life and high levels of depression in those individuals suffering from spinal pain ${ }^{19}$. It is therefore relevant to have Brazilian studies analyzing the prevalence and characteristic of middle aged adults with low back pain in different regions of the country.

It was somewhat surprising not to find a clear relationship between low back pain and any of the parameters studied in this pilot project. Gender, BMI and the number of hours spent sitting at work did not correlate with the presence of low back pain or the perceived need for medical care. However, the correlation between low back pain and BMI has been challenged by others ${ }^{20}$, and the correlation between low back pain and a sedentary lifestyle is far from clear ${ }^{21,22}$. The marginal positive relation between low back pain and load handling at work suggests that occupational hazards need to be much better investigated in population studies. Likewise, the marginally negative relationship between regular physical activity and low back pain equally suggests that assessment of body postures and muscle strength may be important for further research work. Future studies with larger populations may clarify whether these findings are really relevant.

\section{REFERENCES}

1. Johannes CB, Le TK, Zhou X, et al. The prevalence of chronic pain in United States adults: results of an internet-based survey. J Pain 2010;11(11):1230-9.

2. Wong WS, Fielding R. Prevalence and characteristics of chronic pain in the general population of Hong Kong. J Pain 2011;12(2):236-45.

3. Silva MC, Fassa AG, Valle NC. Chronic low back pain in a Southern Brazilian adult population: prevalence and associated factors. Cad Saude Publica 2004;20(2):377-85. 4. Freburger JK, Holmes GM, Agans RP, et al. The rising prevalence of chronic low back pain. Arch Intern Med 2009;169(3):251-8.

5. Carey TS, Freburger JK, Holmes GM, et al. Race, care seeking, and utilization for chronic back and neck pain: population perspectives. J Pain 2010;11(4):343-50.

6. Harms MC, Peers CE, Chase D. Low back pain: what determines functional outcome at six months? An observational study. BMC Musculoskelet Disord 2010;11:236. 7. Heuch I, Hagen K, Heuch I, et al. The impact of body mass index on the prevalence of low back pain: the HUNT study. Spine 2010;35(7):764-8.

8. Chen SM, Liu MF, Cook J, et al. Sedentary lifestyle as 
a risk factor for low back pain: a systematic review. Int Arch Occup Environ Health 2009;82(7):797-806.

9. Wai EK, Roffey DM, Bishop P, et al. Causal assessment of occupational bending or twisting and low back pain: results of a systematic review. Spine J 2010;10(1):76-88. 10. Abreu AM, Faria CD, Cardoso SM, et al. The Brazilian version of the Fear Avoidance Beliefs Questionnaire. Cad Saude Publica 2008;24(3):615-23.

11. Silva MC, Fassa AG, Valle NC. Chronic low back pain in a Southern Brazilian adult population: prevalence and associated factors. Cad Saude Publica 2004;20(2):377-85. 12. Rasmussen C, Leboeuf-Yde C, Hestbaek L, et al. Poor outcome in patients with spine-related leg or arm pain who are involved in compensation claims: a prospective study of patients in the secondary care sector. Scand J Rheumatol 2008;37(6):462-8.

13. Ribeiro LH, Jennings F, Jones A, et al. Effectiveness of a back school program in low back pain. Clin Exp Rheumatol 2008;26(1):81-8.

14. Stanton TR, Latimer J, Maher CG, et al. How do we define the condition 'recurrent low back pain'? A systematic review. Eur Spine J 2010;19(4):533-9.

15. Helfenstein Junior $M$, Goldenfum $M A$, et al. Occupational low back pain. Rev Assoc Med Bras 2010;56(5):583-9.

16. Foss MHD, Martins MRI, Ikehara E, et al. Quali- ty of life of employees with low back pain. Rev Dor 2009;10(2):106-12.

17. Leboeuf-Yde C, Fejer R, Nielsen J, et al. Consequences of spinal pain: Do age and gender matter? A Danish cross-sectional population-based study of 34,902 individuals 20-71 years of age. BMC Musculoskelet Disord. 2011;12:39.

18. Depalma MJ, Ketchum JM, Saullo T. What is the source of chronic low back pain and does age play a role? Pain Med 2011;12(2):224-33.

19. Fernández-de-las-Peñas C, Hernández-Barrera V, Alonso-Blanco $\mathrm{C}$, et al. Prevalence of neck and low back pain in community-dwelling adults in Spain: a population-based national study. Spine 2011;36(3):E213-9.

20. Morais A, Barcelos A. Low back pain--the relevance of a symptom. Acta Reumatol Port 2009;34(1):112-6.

21. Mirtz TA, Greene L. Is obesity a risk factor for low back pain? An example of using the evidence to answer a clinical question. Chiropr Osteopat 2005;13(1):2.

22. Sitthipornvorakul E, Janwantanakul P, Purepong N, et al. The association between physical activity and neck and low back pain: a systematic review. Eur Spine J 2010 Nov 27. [Epub ahead of print]

Presented in December, 21, 2010.

Accepted in March, 20, 2011. 